\title{
VALIDASI BUKU PENILAIAN BERBASIS LITERASI SAINS (BuPeNa BeRiSi) UNTUK CALON GURU SEKOLAH DASAR
}

\author{
Ifa Seftia Rakhma Widiyanti ${ }^{1}$, Saeful Mizan ${ }^{2}$ \\ ${ }^{1}$ Pendidikan Biologi/ Universitas PGRI Ronggolawe Tuban \\ Email: ifaseftia@gmail.com \\ ${ }^{2}$ Pendidikan Guru Sekolah Dasar/ Universitas PGRI Ronggolawe Tuban \\ Email: miz zhan@yahoo.com
}

\begin{abstract}
Abstrak
Tujuan dari penelitian ini yaitu untuk menemukan bentuk Buku Penilaian berbasis Literasi Sains (BuPena BeRiSi) dengan tujuan khusus untuk mengetahui kevalidan Buku Penilaian berbasis Literasi Sains(BuPena BeRiSi). Penelitian ini dilaksanakan di Universitas PGRI Ronggolawe Tuban (UNIROW) program studi Pendidikan Guru Sekolah Dasar (PGSD). Obyek penelitian adalah mahasiswa PGSD UNIROW angkatan 2019. Desain penelitian yang digunakan dalam penelitian ini adalah model pengembangan Dick and Carey. Desain penelitian ini digunakan karena lebih spesifik dalam pengembangannya. Pada tahap awal penelitian dilaksanakan research yaitu tahapan penelitian atau studi literatur untuk mendapatkan informasi tentang kebutuhan produk yang akan dikembangkan. Tahap-tahap pengembangan yang dilakukan terdiri dari tujuh tahapan yaitu (1) analisis kebutuhan, (2) analisis bentuk BuPena BeRiSi, (3) analisis materi dengan keterampilan yang ingin dicapai, (4) merumuskan tujuan pencapaian keterampilan, (5) mengembangkan BuPena BeRiSi, (6) validasi BuPena BeRiSi, (7) revisi BuPena BeRiSi. Hasil validasi menunjukkan bahwa penilaian komponen kesesuaian isi dan kebahasaan mendapatkan kriteria baik. Komponen kegrafikan dan kesesuaian syarat teknis memperoleh kriteria baik sekali. Komponen yang mendapatkan persentase skor tertinggi adalah komponen kegrafikan dengan persentase skor sebesar 91,67 \%. Komponen kesesuaian syarat teknis memperoleh skor 90,63\% dengan kriteria baik sekali. Komponen kesuaian isi dan kebahasaan memperoleh skor sebesar $75 \%$ dengan kategori baik.
\end{abstract}

Kata kunci: buku, penilaian, literasi, sains

\begin{abstract}
The purpose of this study was to find a Assessment Book based Science Literacy with the specific aim of knowing the validity of it. This research was conducted at the PGRI Ronggolawe University Tuban (UNIROW) for students of PGSD UNIROW class 2019. The research design used in this study was the Dick and Carey development model. This research design is used because it is more specific in its development. In the early stages of the research, research was carried out, namely the research stage or literature study to obtain information about the product needs to be developed. The development stages consist of seven stages, they were (1) needs analysis, (2) analysis of the form of BuPena BeRiSi, (3) analysis of the material with the skills to be achieved, (4) formulating goals for achieving skills, (5) developing BuPena BeRiSi , (6) BuPena BeRiSi validation, (7) BuPena BeRiSi revision. The validation results show that the assessment of the content and language suitability components gets good criteria. The graphic components and the conformity of the technical requirements obtain excellent criteria. The component that got the highest percentage score was the graphic component with a score percentage of $91.67 \%$. The suitability component of the technical requirements obtained a score of $90.63 \%$ with excellent criteria. The content and language suitability components obtained a score of $75 \%$ in the good category.
\end{abstract}

Keywords: book, assessment, literacy, science 


\section{Pendahuluan}

Pergeseran tujuan pendidikan nasional merupakan akibat perubahan zaman. Menghasilkan lulusan yang memiliki kemampuan literasi baru meliputi literasi data, literasi teknologi, dan literasi manusia yang berakhlak mulia berdasarkan pemahaman keyakinan agama merupakan tantangan yang dihadapi oleh perguruan tinggi dalam pengembangan kurikulum di era Industri 4.0 (Kemdikbud, 2020). Literasi merupakan rangkaian pengetahuan, keterampilan, dan strategi yang berkembang yang dibangun individu sepanjang hidup yang melibatkan mobilisasi keterampilan kognitif dan praktis, dan sumber daya lainnya seperti sikap, motivasi dan nilai-nilai (OECD, 2013). Salah satu program penilaian internasional yaitu Programme for International Student Assessment (PISA) mengumpulkan informasi literasi membaca, sains, dan matematika siswa yang reliabel setiap tiga tahun. Setiap tiga tahun fokus penilaian PISA berbeda. Pada tahun 2018, penilaian PISA fokus pada literasi sains. Indonesia menduduki peringkat 70 pada level 1 dari 76 negara anggota OECD (OECD, 2018). Calon guru sekolah dasar akan menyalurkan pengetahuan dan pengalamannya kepada peserta didiknya kelak. Oleh karena itu, mahasiswa Pendidikan Guru
Sekolah Dasar harus memperoleh pengalaman belajar yang dapat dimanfaatkan setelah selesai menempuh pendidikan.

Pengalaman belajar diperoleh dari kegiatan pembelajaran di kelas. Rancangan kegiatan pembelajaran harus disusun sebelum proses pembelajaran di kelas dilaksanakan. Tujuan pengajaran harus ada di dalam rancangan kegiatan sebagai target yang diharapkan dari proses belajar mengajar dan cara bagaimana tujuan dan proses belajar mengajar tersebut dapat dicapai dengan efektif (Widoyoko, 2013). Berdasarkan rencana dan tujuan yang telah ditetapkan, dilaksanakan kegiatan pembelajaran. Kesesuaian antara kegiatan pengajaran dengan tujuan, tingkat penguasaan materi peserta didik, dan keefektifan proses pembelajaran diperoleh dari kegiatan asesmen (Arifin, 2017). Data kemampuan literasi sains mahasiswa PGSD di kabupaten Tuban masih rendah diketahui dari hasil penelitian Winata, dkk (2016) Oleh karena itu, peneliti melakukan penelitian yang berjudul Pengembangan Buku Penilaian berbasis Literasi Sains (BuPena BeRiSi) untuk Mahasiswa PGSD di UNIROW Tuban. 
MetodePenelitian

Tujuan dari penelitian ini yaitu untuk mengembangkan buku penilaian berbasis literasi sains (BuPena BeRiSi) untuk mahasiswa sehingga dikategorikan sebagai penelitian pengembangan ( $R$ \& $D)$. Penelitian ini dilaksanakan pada mahasiswa PGSD Universitas PGRI Ronggolawe Tuban (UNIROW) program studi Pendidikan Guru Sekolah Dasar (PGSD) angkatan 2019 tahun 2019/2020. Waktu penelitian dimulai bulan April tahun 2020 sampai dengan bulan Agustus tahun 2020. Model pengembangan Dick and Carey dipilih sebagai desain penelitian ini (Aji, 2016). Desain penelitian pengembangan Dick and Carey terdiri dari 7 langkah pelaksanaan strategi penelitian dan pengembangan. Desain penelitian ini digunakan karena lebih spesifik dalam pengembangannya. Pada tahap awal penelitian dilaksanakan research yaitu tahapan penelitian atau studi literatur untuk mendapatkan informasi tentang kebutuhan produk yang akan dikembangkan. Tahap pengembangan yang digunakan terdiri dari sepuluh tahapan yaitu (1) analisis kebutuhan, (2) analisis bentuk BuPena BeriSi, (3) analisis materi dengan keterampilan yang ingin dicapai, (4) merumuskan tujuan pencapaian keterampilan, (5) mengembangkan BuPena Berisi, (6) validasi BuPena BeriSi, (7) revisi BuPena BeriSi. Produk BuPena Berisi belum diujicobakan secara luas karena terhambat pandemi Covid-19.

\section{Hasil dan Pembahasan}

Analisis Kebutuhan

Pengembangan Buku Penilaian berbasis Literasi Sains (BuPena BeRiSi) berawal dari tujuan literasi sains untuk peserta didik supaya siap menghadapi Revolusi Industri 4.0 (Junaidi, 2020). Selain itu, latar belakang dikembangkannya Buku Penilaian berbasis Literasi Sains (BuPena BeRiSi) diperoleh dari analisis kemampuan literasi sains mahasiswa yang masih rendah (Winata, dkk, 2016). Buku ajar yang dilengkapi soal-soal belum menyajikan materi dan soal berbasis literasi sains. Oleh karena itu dikembangkan Buku Penilaian berbasis Literasi Sains (BuPena BeRiSi).

\section{Analisis Bentuk Buku Penilaian} berbasis Literasi Sains (BuPena

\section{BeRiSi)}

Buku Penilaian berbasis Literasi Sains (BuPena BeRiSi) berbentuk buku cetak dengan ukuran A5. Buku Penilaian berbasis Literasi Sains (BuPena BeRiSi) terdiri dari dua buku yaitu Buku Penilaian berbasis Literasi Sains (BuPena BeRiSi) untuk mahasiswa dan Pedoman Buku 23 | Validasi Buku Penilaian Berbasis Literasi Sains (Bupena Berisi) untuk....... 
Penilaian berbasis Literasi Sains yang rendah untuk keempat materi (BuPena BeRiSi) yang ditujukan untuk tersebut. Pertanyaan-pertanyaan yang dosen. Buku Penilaian berbasis Literasi disajikan berupa soal pilihan ganda Sains (BuPena BeRiSi) untuk dengan lima (5) pilihan jawaban. mahasiswa berisi petunjuk pengerjaan Berdasarkan penelitian Bhakti (2015) soal-soal pilihan ganda berbasis literasi pertanyaan yang menyajikan pilihan sains, soal-soal pilihan ganda berbasis jawaban menunjukkan hasil yang lebih literasi sains yang berjumlah 22 soal, akurat untuk menunjukkan kemampuan dan lembar jawaban. Buku Penilaian mahasiswa.

berbasis Literasi Sains (BuPena BeRiSi) untuk dosen berisi uraian tentang penilaian, literasi sains, pedoman penilaian, kisi-kisi soal, dan kunci jawaban soal-soal pilihan ganda berbasis literasi sains. Bobot soal ditentukan oleh level indikator literasi sains.

Analisis Materi dengan Keterampilan yang Ingin Dicapai

Soal-soal pilihan ganda berbasis literasi sains yang dikembangkan terdiri dari empat bab antara lain 1) Bab Suhu yang terdiri dari 5 butir soal dengan jumlah skor keseluruhan 25, 2) Bab Energi yang terdiri dari 5butir soal dengan jumlah skor keseluruhan 23, 3) Bab Cahaya, sejumlah 6 soal dengan jumlah skor keseluruhan 25, dan 4) Bab Perkembangan Makhluk Hidup yang terdiri dari 6 soal dengan jumlah skor keseluruhan 27. Sehingga nilai akhir dari 22 soal sejumlah 100 . Keempat materi dipilih berdasarkan hasil pretest kemampuan literasi sains mahasiswa

Merumuskan Tujuan Pencapaian Keterampilan

Analisis tujuh indikator BuPena BeRiSi sesuai dengan capaian pembelajaran pada mata kuliah konsep IPA di SD untuk mahasiswa PGSD yaitu Diharapkan apabila selesai menempuh mata kuliah konsep IPA di sekolah dasar, mahasiswa mempunyai pemahaman tentang konsep-konsep dan teori-teori dasar IPA, fenomenafenomena alam, dan gejala-gejala alam dan terampil mengaplikasikan konsep IPA secara logis, kritis, sistematis, dan inovatif dalam setiap pembelajaran IPA di kelas rendah maupun kelas tinggi.

\section{Mengembangkan BuPena BeRiSi}

Setelah melalui tahap-tahap di atas, ditentukan bentuk BuPena BeRiSi berupa buku cetak berukuran A5 yang terdiri dari dua buku yaitu Buku Penilaian Berbasis Literasi Sains untuk Mahasiswa dan Pedoman Buku Penilaian Berbasis 
Literasi Sains untuk Dosen. Terdapat yang dilakukan disajikan pada Tabel 1. beberapa revisi dari hasil validasi. Revisi

Tabel 1. Revisi Validasi

\begin{tabular}{l} 
No. Komponen \\
\hline \multicolumn{1}{c}{ Sebelum Revisi } \\
$\begin{array}{l}\text { Cover BuPena Berisi untuk } \\
\text { Mahasiswa }\end{array}$
\end{tabular}

Soal nomor 18 , cek kembali kata-kata dalam soal.

2. Terdapat "tiga" pot tapi soal menyajikan kata "Kedua" pot
Nisa melakukan pengamatan pertumbuhan biji kacang. Menurutnya, pemberian pupuk Urea pada saat pertumbuhan biji kacang akan meningkatkan kecepatan perkecambahan. Untuk membuktikan hal tersebut, Nisa merancang percobaan dengan menggunakan 3 pot yang berbeda yang ditanami biji dengan spesies dan jumlah yang sama. Pot $A$ ditanami biji dengan memberikan air biasa, pot $B$ ditanami biji dan ditambahkan larutan pupuk urea sebesar $5 \%$ dan pot $\mathrm{C}$ ditanami biji dan ditambahkan larutan pupuk ZA sebesar $5 \%$. Kedua pot diletakkan pada tempat yang sama intensitas cahayanya. Setiap hari selama lima hari siswa tersebut melakukan pengukuran pertumbuhan tinggi batang pada kedua pot.
Nisa melakukan pengamatan pertumbuhan biji kacang. Menurutnya, pemberian pupuk Urea pada saat pertumbuhan biji kacang akan meningkatkan kecepatan perkecambahan. Untuk membuktikan hal tersebut, Nisa merancang percobaan dengan menggunakan 3 pot yang berbeda yang ditanami biji dengan spesies dan jumlah yang sama. Pot $A$ ditanami biji dengan memberikan air biasa, pot $B$ ditanami biji dan ditambahkan larutan pupuk urea sebesar $5 \%$ dan pot $C$ ditanami biji dan ditambahkan larutan pupuk ZA sebesar $5 \%$. Ketiga pot diletakkan pada tempat yang sama intensitas cahayanya. Setiap hari selama lima hari siswa tersebut melakukan pengukuran pertumbuhan tinggi batang pada ketiga pot.
Soal nomor 21, perbaiki

3. kalimat soal supaya tidak ambigu
Untuk mengetahui kesimpulan yang tepat tentang data pertumbuhan tinggi bayam, maka kita dapat menyajikan data di atas dalam bentuk ....
Data pada Tabel di atas dapat disajikan dalam bentuk 
Soal-soal disajikan pada mahasiswa secara online menggunakan google form. Hasil pengerjaan mahasiswa hanya bisa diketahui persentasenya tanpa dapat dianalisis secara kuantitatif besarnya tingkat validitas, reliabilitas, tingkat kesukaran soal, dan daya beda soal.

\section{Hasil Validasi Ahli}

Langkah berikutnya setelah mengembangkan produk berupa Buku Penilaian berbasis Literasi Sains (BuPena BeRiSi) yaitu melakukan validasi produk kepada dua validator yaitu: Dr. Tabitha Sri Hartati Wulandari, M.Kes. dan Ir. Hernik Pujiastuti, M. Pd. Komponen yang dinilai oleh kedua validator meliputi komponen kesesuaian isi, kebahasaan, kegrafikan, dan syarat teknis. Data hasil validasi dari kedua validator disajikan pada tabel dan gambar berikut.

\section{Komponen Kesesuaian Isi}

Hasil validasi ahli pada komponen kesesuaian isi disajikan pada Tabel 1.

Tabel 1. Hasil Validasi Komponen Kesesuaian Isi

\begin{tabular}{|c|c|c|c|c|c|}
\hline \multirow{2}{*}{ No } & \multirow{2}{*}{ Indikator Penilaian } & \multicolumn{4}{|c|}{ Alternatif Penilaian } \\
\hline & & 1 (SK) & $2(\mathrm{~K})$ & 3 (B) & $4(\mathrm{SB})$ \\
\hline 1 & $\begin{array}{l}\text { Kesesuaian buku penilaian } \\
\text { berbasis literasi sains } \\
\text { dengan SK-KD }\end{array}$ & & & $\sqrt{ }$ & \\
\hline 2 & $\begin{array}{l}\text { Sistematika dalam } \\
\text { penyusunan komponen } \\
\text { buku penilaian berbasis } \\
\text { literasi sains sudah runtut }\end{array}$ & & & $\sqrt{ }$ & \\
\hline 3 & $\begin{array}{l}\text { Kejelasan setiap } \\
\text { komponen pada buku } \\
\text { penilaian berbasis literasi } \\
\text { sains }\end{array}$ & & & $\sqrt{ }$ & \\
\hline 4 & $\begin{array}{l}\text { Langkah-langkah } \\
\text { penggunaan buku } \\
\text { penilaian berbasis literasi } \\
\text { sains jelas }\end{array}$ & & & $\sqrt{ }$ & \\
\hline 5 & $\begin{array}{l}\text { Permasalahan dalam buku } \\
\text { penilaian berbasis literasi } \\
\text { sains dapat merefleksikan } \\
\text { kemampuan literasi sains } \\
\text { mahasiswa }\end{array}$ & & & $\sqrt{ }$ & \\
\hline 6 & $\begin{array}{l}\text { Pertanyaan dalam buku } \\
\text { penilaian berbasis literasi } \\
\text { sains sesuai dengan } \\
\text { materi pembelajaran IPA } \\
\text { untuk mahasiswa PGSD }\end{array}$ & & & $\sqrt{ }$ & \\
\hline
\end{tabular}


Skor yang diperoleh pada aspek komponen kesesuaian isi dapat disajikan dalam bentuk Gambar 1 .

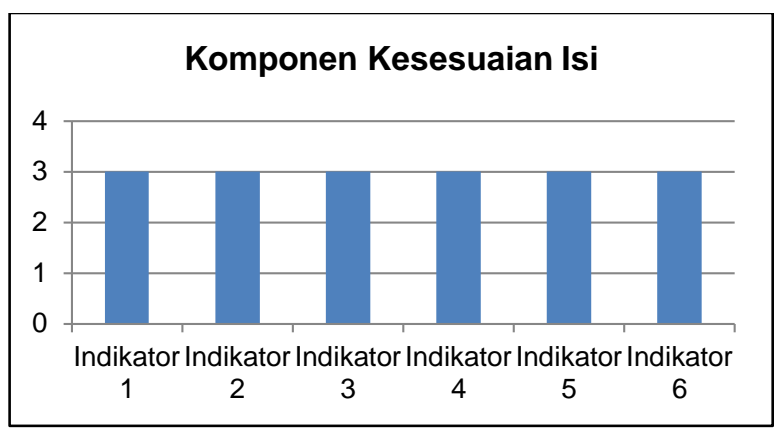

Gambar 1. Grafik Hasil Validasi Komponen Kesesuaian Isi

Gambar 1 menunjukkan bahwa semua indikator memperoleh skor 3 dari validator. Indikator 1 menunjukkan kesesuaian BuPena BeRiSi dengan SK dan KD mata kuliah konsep IPA di SD. Indikator kedua menunjukkan sistematika dalam penyusunan komponen BuPena BeRiSi sudah runtut. Indikator ketiga menunjukkan setiap komponen pada BuPena BeRiSi sudah jelas. Indikator keempat menunjukkan langkah-langkah penggunaan BuPena BeRiSi sudah jelas dengan adanya petunjuk penggunaan BuPena BeRiSi. Indikator kelima menunjukkan permasalahan yang disajikan soal-soal dapat merefleksikan kemampuan literasi sains mahasiswa. Indikator keenam menunjukkan pertanyaan dalam BuPena Berisi sesuai dengan materi IPA untuk mahasiswa PGSD. Komponen kesesuaian isi memperoleh persentase sebesar $75 \%$ dengan kriteria baik.

\section{Komponen Kebahasaan}

Hasil validasi ahli pada komponen kebahasaan ditunjukkan Tabel 2.

Tabel 2. Hasil Validasi Komponen Kebahasaan

\begin{tabular}{|c|l|l|l|l|l|}
\hline \multirow{2}{*}{ No } & \multicolumn{2}{|c|}{ Indikator Penilaian } & \multicolumn{3}{|c|}{ Alternatif Penilaian } \\
\cline { 3 - 6 } & & $\mathbf{1}$ (SK) & 2 (K) & 3 (B) & 4 (SB) \\
\hline 1 & $\begin{array}{l}\text { Kejelasan penggunaan } \\
\text { kalimat dalam buku penilaian } \\
\text { berbasis literasi sains }\end{array}$ & & & $\sqrt{ }$ & \\
\hline 2 & $\begin{array}{l}\text { Kesesuaian kalimat yang } \\
\text { digunakan buku penilaian } \\
\text { berbasis literasi sains dengan } \\
\text { kaedah Bahasa Indonesia } \\
\text { yang baik dan benar }\end{array}$ & & & $\sqrt{ }$ & \\
\hline 3 & $\begin{array}{l}\text { Keefektifan penggunaan } \\
\text { kalimat dalam buku penilaian } \\
\text { berbasis literasi sains }\end{array}$ & & & $\sqrt{ }$ & \\
\hline
\end{tabular}




\begin{tabular}{|c|l|c|c|c|c|}
\hline \multirow{2}{*}{ No } & \multicolumn{1}{|c|}{ Indikator Penilaian } & \multicolumn{3}{|c|}{ Alternatif Penilaian } \\
\cline { 3 - 6 } & \multicolumn{1}{|c|}{$\mathbf{1}$ (SK) } & 2 (K) & 3 (B) & $\mathbf{4}$ (SB) \\
\hline 4 & $\begin{array}{l}\text { Kesesuaian bahasa yang } \\
\text { digunakan pada buku } \\
\text { penilaian berbasis literasi } \\
\text { sains dengan tingkat } \\
\text { intelektual mahasiswa }\end{array}$ & & & & \\
& & & $\sqrt{ }$ & \\
\hline
\end{tabular}

Hasil validasi ahli pada komponen kebahasaan juga ditunjukkan Gambar 2.

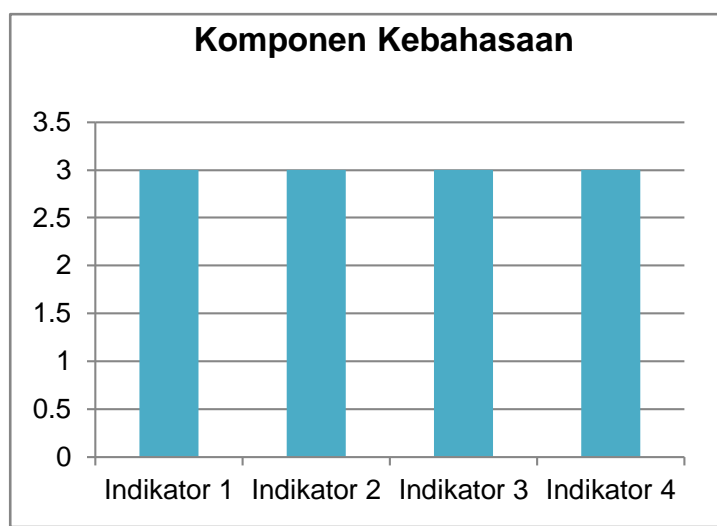

Gambar 2. Grafik Hasil Validasi Komponen Kebahasaan

Hasil validasi ahli diperoleh ratarata skor 3 untuk keempat indikator. BuPena BeRiSi yang akan dikembangkan telah memenuhi komponen kebahasaan antara lain, penggunaan kalimat dalam BuPena BeRiSi jelas, kalimat yang digunakan sesuai kaedah Bahasa Indonesai yang baik dan benar, efektif, dan sesuai dengan tingkat intelektual mahasiswa. Aspek kebahasaan memperoleh presentase sebesar $75 \%$ dengan kriteria baik.

\section{Aspek Komponen Kegrafikan}

Komponen

kegrafikan memperoleh validasi dari ahli yang disajikan Tabel 3.

Tabel 3. Hasil Validasi Komponen Kegrafikan

\begin{tabular}{|c|c|c|c|c|c|}
\hline \multirow{2}{*}{ No } & \multirow{2}{*}{ Indikator Penilaian } & \multicolumn{4}{|c|}{ Alternatif Penilaian } \\
\hline & & 1 (SK) & $2(K)$ & 3 (B) & 4 (SB) \\
\hline 1 & $\begin{array}{l}\text { Kesesuaian ukuran Buku } \\
\text { Penilaian berbasis Literasi } \\
\text { Sains (BuPena BerISi) }\end{array}$ & & & & $\sqrt{ }$ \\
\hline 2 & $\begin{array}{l}\text { Kesesuaian dalam pemilihan } \\
\text { jenis huruf dan angka pada } \\
\text { Buku Penilaian berbasis } \\
\text { Literasi Sains (BuPena } \\
\text { BerISi) }\end{array}$ & & & & $\sqrt{ }$ \\
\hline 3 & $\begin{array}{l}\text { Kemenarikan dalam desain } \\
\text { pada Buku Penilaian } \\
\text { berbasis Literasi Sains } \\
\text { (BuPena BerlSi) }\end{array}$ & & & $\sqrt{ }$ & \\
\hline 4 & $\begin{array}{l}\text { Proporsionalitas tata letak } \\
\text { teks dan gambar dalam Buku } \\
\text { Penilaian berbasis Literasi }\end{array}$ & & & & $\sqrt{ }$ \\
\hline
\end{tabular}




\begin{tabular}{|c|c|c|c|c|c|}
\hline \multirow{2}{*}{ No } & \multirow{2}{*}{ Indikator Penilaian } & \multicolumn{4}{|c|}{ Alternatif Penilaian } \\
\hline & & 1 (SK) & $2(K)$ & 3 (B) & 4 (SB) \\
\hline 1 & $\begin{array}{l}\text { Kesesuaian ukuran Buku } \\
\text { Penilaian berbasis Literasi } \\
\text { Sains (BuPena BerISi) }\end{array}$ & & & & $\sqrt{ }$ \\
\hline & Sains (BuPena BerlSi) & & & & \\
\hline 5 & $\begin{array}{l}\text { Kemenarikan dalam } \\
\text { pemilihan gambar pada Buku } \\
\text { Penilaian berbasis Literasi } \\
\text { Sains (BuPena BerISi) }\end{array}$ & & & & $\sqrt{ }$ \\
\hline 6 & $\begin{array}{l}\text { Ketepatan dalam pemilihan } \\
\text { warna pada Buku Penilaian } \\
\text { berbasis Literasi Sains } \\
\text { (BuPena BerISi) }\end{array}$ & & & $\sqrt{ }$ & \\
\hline
\end{tabular}

Skor yang diberikan validator pada indikator keeam yaitu pemilihan warna komponen kegrafikan juga disajikan pada Gambar 3.

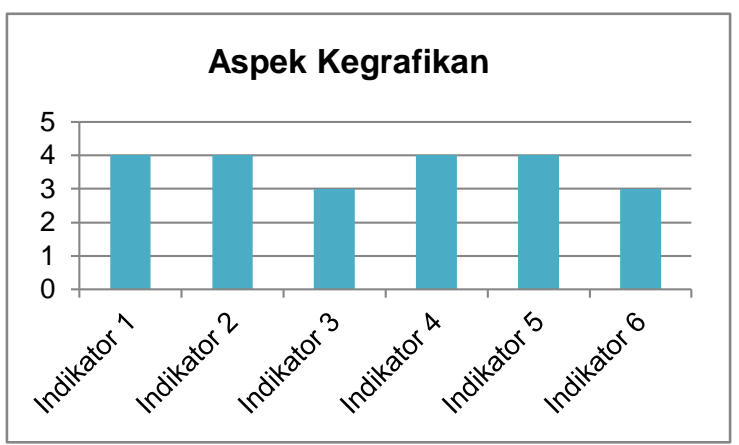

\section{Gambar 3. Grafik Hasil Validasi Aspek Kegrafikan}

Minat

$$
\text { mahasiswa }
$$$$
\text { soal-soal }
$$

mengerjakan soal-soal diharapkan

meningkat jika komponen kegrafikan

juga diperhatikan dalam pengembangan

BuPena BeRiSi. Terdapat enam (6)

indikator pada aspek kegrafikan. pada BuPena memperoleh skor 3 karena warna yang digunakan pada cover BuPena BeRiSi untuk dosen berwarna merah. Menurut validator hal tersebut menyebabkan tampilan BuPena Berisi kurang menarik. Untul indikator ukuran buku, pemilihan jenis huruf, tata letak teks, dan kemarikan gambar validator memberikan skor 4. Komponen kegrafikan memperoleh presentase sebesar 91,67\% dengan kriteria baik sekali.

\section{Komponen Kesuaian Syarat teknis}

Hasil validasi pada aspek komponen kesesuaian syarat teknis disajikan pada Tabel 4.

Indikator 3 yaitu kemenarikan desain dan

Tabel 4. Hasil Validasi Komponen Kesesuaian Syarat Teknis

\begin{tabular}{|c|l|c|c|c|c|}
\hline \multirow{2}{*}{ No } & \multicolumn{1}{|c|}{ Indikator Penilaian } & \multicolumn{4}{|c|}{ Alternatif Penilaian } \\
\cline { 3 - 6 } & & $\mathbf{1}(\mathbf{S K})$ & $\mathbf{2}$ (K) & $\mathbf{3}$ (B) & $\mathbf{4}$ (SB) \\
\hline 1 & $\begin{array}{l}\text { Buku Penilaian berbasis } \\
\text { Literasi Sains (BuPena } \\
\text { BerlSi) memberikan } \\
\text { kesempatan kepada semua } \\
\text { mahasiswa untuk mengetahui }\end{array}$ & & & & \\
\hline
\end{tabular}

29 | Validasi Buku Penilaian Berbasis Literasi Sains (Bupena Berisi) untuk....... 


\begin{tabular}{|c|c|c|c|c|c|}
\hline \multirow{2}{*}{ No } & \multirow{2}{*}{ Indikator Penilaian } & \multicolumn{4}{|c|}{ Alternatif Penilaian } \\
\hline & & 1 (SK) & $2(K)$ & $3(B)$ & 4 (SB) \\
\hline & kemampuan literasi sains & & & & \\
\hline 2 & $\begin{array}{l}\text { Buku Penilaian berbasis } \\
\text { Literasi Sains (BuPena } \\
\text { BerISi) menghubungkan ilmu } \\
\text { pengetahuan dan teknologi } \\
\text { dengan kehidupan sehari-hari }\end{array}$ & & & $\sqrt{ }$ & \\
\hline 3 & $\begin{array}{l}\text { Buku Penilaian berbasis } \\
\text { Literasi Sains (BuPena } \\
\text { BerISi) menuntun mahasiswa } \\
\text { dalam melakukan kajian } \\
\text { literatur }\end{array}$ & & & & $\sqrt{ }$ \\
\hline 4 & $\begin{array}{l}\text { Buku Penilaian berbasis } \\
\text { Literasi Sains (BuPena } \\
\text { BerISi) melatih mahasiswa } \\
\text { dalam melakukan } \\
\text { perhitungan kuantitatif }\end{array}$ & & & $\sqrt{ }$ & \\
\hline 5 & $\begin{array}{l}\text { Buku Penilaian berbasis } \\
\text { Literasi Sains (BuPena } \\
\text { BerISi) melatih mahasiswa } \\
\text { dalam membuat grafik } \\
\text { berdasarkan data }\end{array}$ & & & $\sqrt{ }$ & \\
\hline 6 & $\begin{array}{l}\text { Buku Penilaian berbasis } \\
\text { Literasi Sains (BuPena } \\
\text { BerISi) melatih mahasiswa } \\
\text { untuk mengembangkan } \\
\text { kemampuan menganalisis }\end{array}$ & & & & $\sqrt{ }$ \\
\hline 7 & $\begin{array}{l}\text { Buku Penilaian berbasis } \\
\text { Literasi Sains (BuPena } \\
\text { BerISi) melatih mahasiswa } \\
\text { dalam memperoleh } \\
\text { pengalaman belajar melalui } \\
\text { keterampilan berpikir dan } \\
\text { berkomunikasi }\end{array}$ & & & & $\sqrt{ }$ \\
\hline 8 & $\begin{array}{l}\text { Buku Penilaian berbasis } \\
\text { Literasi Sains (BuPena } \\
\text { BerISi) melatih mahasiswa } \\
\text { melatih siswa dalam } \\
\text { membuat kesimpulan }\end{array}$ & & & & $\sqrt{ }$ \\
\hline
\end{tabular}


Data hasil validasi pada komponen kesesuaian Syarat Teknis juga disajikan pada Gambar 4.

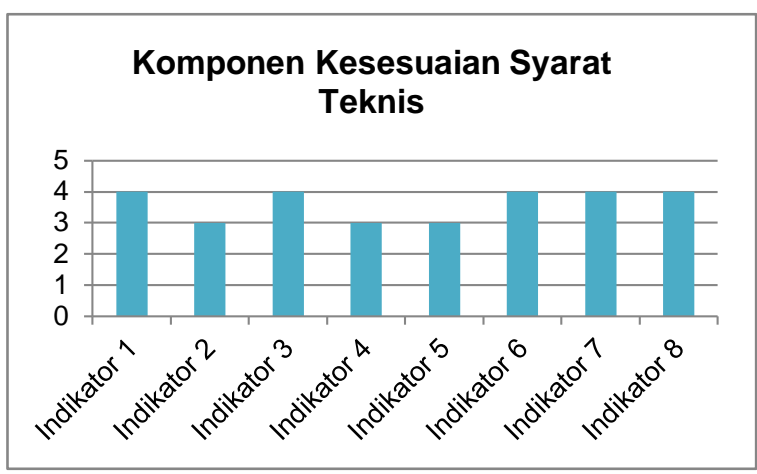

\section{Gambar 4. Grafik Hasil Validasi Komponen Kesesuaian Syarat Teknis}

Komponen kesesuaian syarat teknis disajikan untuk mengetahui indikator-indikator literasi sains di dalam BuPena BeRiSi. Indikator 1 menunjukkan BuPena Berisi memberikan kesempatan kepada semua mahasiswa untuk mengetahui kemampuan literasi sainsnya. Indikator 2 menunjukkan (BuPena BeRiSi) menghubungkan ilmu pengetahuan dan teknologi dengan kehidupan sehari-hari. Indikator 3 menunjukkan (BuPena BeRiSi) menuntun mahasiswa dalam melakukan kajian literatur. Indikator 4 menunjukkan (BuPena BeRiSi) melatih mahasiswa dalam melakukan perhitungan kuantitatif. Indikator 5 menunjukkan (BuPena BeRiSi) melatih mahasiswa dalam membuat grafik berdasarkan data . Indikator 6 menunjukkan (BuPena BeRiSi) melatih mahasiswa untuk mengembangkan kemampuan menganalisis . Indikator 7 menunjukkan (BuPena BeRiSi) melatih mahasiswa dalam memperoleh pengalaman belajar melalui keterampilan berpikir dan berkomunikasi . Indikator 8 menunjukkan melatih mahasiswa dalam membuat kesimpulan. Validator memberikan skor 3 untuk indikator ke-2. $\mathrm{Ke}-4$, dan ke-5. Indikator 1,3,6,7,8 memperoleh skor 4 dari validator. Komponen keseuaian syarat teknis memperoleh presentase sebesar 90,63 $\%$ dengan kriteria baik sekali.

Data hasil validasi menunjukkan bahwa penilaian komponen kesesuaian isi dan kebahasaan mendapatkan kriteria baik. Komponen kegrafikan dan kesesuaian syarat teknis memperoleh kriteria baik sekali. Komponen yang mendapatkan persentase skor tertinggi adalah komponen kegrafikan dengan persentase skor sebesar 91,67 \%. Komponen kesesuaian syarat teknis memperoleh skor 90,63 \% dengan kriteria baik sekali. Komponen kesuaian isi dan kebahsaan memperoleh skor sebesar $75 \%$ dengan kategori baik yang berarti bahwa harus ada perbaikan di dalam kalimat -kalimat soal dan petunjuk penggunaan BuPena BeRiSi. 


\section{Kesimpulan}

Hasil validasi menunjukkan bahwa penilaian komponen kesesuaian isi dan kebahasaan mendapatkan kriteria baik. Komponen kegrafikan dan kesesuaian syarat teknis memperoleh kriteria baik sekali. Komponen yang mendapatkan persentase skor tertinggi adalah komponen kegrafikan dengan persentase skor sebesar 91,67 \%. Komponen kesesuaian syarat teknis memperoleh skor 90,63 \% dengan kriteria baik sekali. Komponen kesuaian isi dan kebahasaan memperoleh skor sebesar $75 \%$ dengan kategori baik. Berdasarkan hasil ini, penggunaan BuPena BeRiSi layak untuk diujicobakan pada mahasiswa.

Soal-soal yang disajikan online kepada mahasiswa sebaiknya menggunakan aplikasi yang dapat mengolah data kualitas soal seperti validitas, reliabilitas, tingkat kesukaran, dan daya beda soal, sehingga soal-soal yang disajikan lebih valid.

\section{DaftarPustaka}

Aji, W. N. (2016). Model Pembelajaran Dick and Carrey Dalam Pembelajaran Bahasa dan Sastra Indonesia. Jurnal Kajian Linguistik dan Sastra, 1 (2): 119-126.

Arifin, Z. (2017). Evaluasi Pembelajaran (Prinsip, Teknik, Prosedur). PT. Remaja Rosdakarya: Bandung.

Bhakti, Yoga Budi. (2015). Pengaruh Jumlah Alternatif Jawaban dan Teknik Penskoran Terhadap Reliabilitas Tes. Jurnal Formatif, 5 (1): 1-13.

Kemdikbud. (2020). Buku Panduan Merdeka Belajar Kampus Merdeka. mdikbud: Jakarta.

OECD. (2013). PISA 2012 Assessment and Analytical Framework (Mathematics, Reading, Problem Solving, and Financial Literacy). OECD Publishing: France.

OECD. (2018). PISA 2015 Result in Focus. OECD Publishing: France.

Widoyoko, S. E. P. (2013). Evaluasi Program Pembelajaran. Yogyakarta: Pustaka Belajar.

Winata, A, Sri Cacik, Ifa Seftia R.W. (2016). Analisis Kemampuan Awal Literasi Sains Mahasiswa pada Konsep IPA. Education and Human Development Journal, 1(1):34-39. 